\title{
THE IMAGE OF ZAGREB AS A SECOND METROPOLIS WITHIN YUGOSLAVIA
}

Keywords: modernization, urban planning, Zagreb, identity, symbolization, urban icon, postcard, pin, communism, capitalism

\section{Introduction}

The concept and function of a metropolis, in the scope of geography and politics, had an enormous impact on shaping the city of Zagreb during its three modernizations. The second modernization was articulated by two parallel processes, urbanization and industrialization; repercussions on the city's development can therefore be traced at several levels. The first modernization, from the 1860s to the First World War, was marked by ethnic integration and social modernization, which required a definition of Zagreb as a Croatian ethnic center (Rogić, 2007 39). Although Zagreb still was not truly a metropolis during this period, it functioned as an idea of a future capital. It was this period when the first Lower Town of Zagreb was formed, whose rectangular grid network following the rhythm of greenery, prominent bourgeois buildings, and scientific institutions defined Zagreb as far as the railway station. The urban fabric, together with its architectural features, clearly suggested the influence of Vienna, the capital of the Habsburg monarchy.

The first large-scale expansion of Zagreb that made a radical break with the vision of the city as far as the railway, however, happened during its second modernization within communist Yugoslavia. As Josip Broz "Tito" observed, Zagreb was a second metropolis (Blau, Rupnik, 2007, 213) whose urban, economic, and cultural growth represented the center of Croatia. 




figure 1: Pin with the sign 'With workers' solidarity 1000 new apartments' source: I. Podnar

The working class became a legitimizing basis under the new system, and so this agricultural country was tasked with creating, in a short period of time, the necessary conditions for rise of this new dominant social class. By 1900 (i.e., by the time Croatia had achieved a degree of autonomy), Zagreb had assumed integrating characteristics: accelerated spatial, population, industrial, and transport growth; establishment as the regional and political center; and a place that attracted new immigrants. This partially resulted from the natural processes of urban growth, but mostly from the articulation of new sociopolitical relations. 
By analyzing three planned and developed city spaces-Vukovar Street (formerly Moscow Boulevard and Street of the Proletarian Brigades), the Zagreb Fairground, and New Zagreb-the spatial identity systems of Zagreb as a metropolis in the second modernization can be recognized. Their symbolization, summed up in postcards, souvenirs, pins, maps, and so on, represents implementation of the new social, political, and urban values among the widest social groups.

However, the third modernization that began in the 1990s sublimed its values in completely different visual forms. Taking into account the fact that urban memory is relatively long and that the rhythm of changes in the same space is very dynamic, symbolic language mediates the mixed values of the two successive, but principally opposed systems. Although the iconicity of the city is a dynamic and changeable category, there are constant, firm identity points present both within the citizens' awareness and visual dissemination. It is exactly those permanent urban icons that fix the idea of a place and its values that persist independent of the ideologies that come from outside and above. In addition to these firm points, each time period implements its own typical metonymic structures that form a site- and time-specific urban, cultural, social, and political environment in a dialogue with what is already present.

\section{Vukovar Street}

Until the end of the First World War, urbanized space up to the railway was sufficient for Zagreb. Significant population growth and postwar settlement created a strong need to expand the urban space southwards, toward the Sava River. The key ideas of urbanization options were presented at an international competition in 1930. Although no prizes were awarded, this showed a dominant orientation towards the modern urban and architectural principles of the International Congresses of Modern Architecture (CIAM; Blau, Rupnik, 2007, 164). These principles, contextualized as part of the new political and social system after the Second World War, were realized in the construction of Moscow Boulevard (Moskovski bulevar, re- 
named Beogradski bulevard 'Belgrade Boulevard' in 1948, then renamed Ulica proletarskih brigada 'Street of the Proletarian Brigades' in 1954, and finally renamed Ulica grada Vukovara 'Vukovar Street'). This genealogy of the street's name suggests its symbolic value and reflects the complex social scene of this east-west artery.

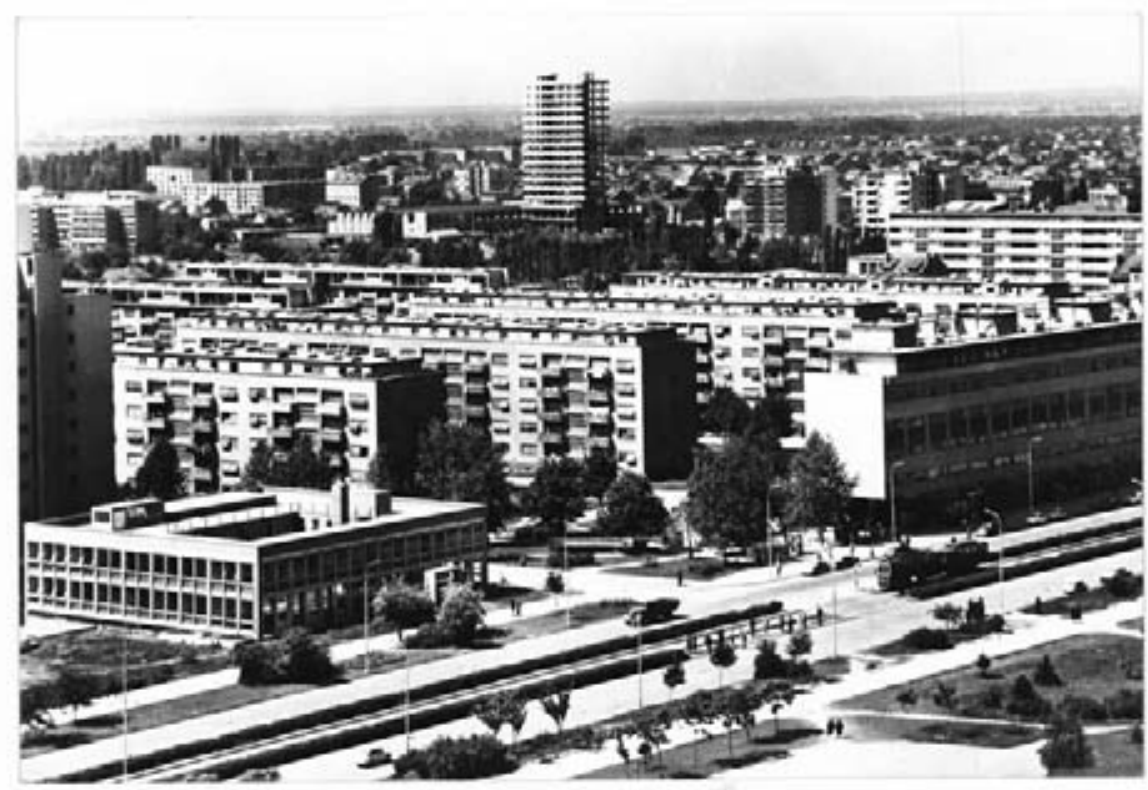

figure 2: Postcard with Vukovar Street - view at southwestern part of the street with residential building by Neven Segvic built in 1947-49 (right) and Vjesnik Skyscraper during construction in the background (Antun Ulrich, 1972) source: Croatian State Archives

In 1947 Vladimir Antolić created the General Plan for Zagreb, which drew on various experiences, from Le Corbusier to the CIAM and free urban planning, in order to make Vukovar Street flexible enough for future development, both human and technocratic, in line with the ideology of industrial progress and concern for collective needs. In its main features, this wide road represents the turning point in Zagreb urbanism in form and symbolism. It was defined by apartment buildings set transverse to the road, built following modern principles, with reinforced concrete, raised 
on pillars, and governed by workers' self management units, following a plan that rejected the city-block-based architecture of the nineteenth-century Lower Town. Although built following drafts of directive regulations (Ivanković, 2006 192), the construction was almost programmatic. "The construction of new Zagreb (Novi Zagreb) must be based on new surfaces that enable free shaping of new urban thought, that will satisfy the demands of the functionality of living relations with new social reality, but will simultaneously interpret the emotions of art experiences expressed in the urban and architectural compositions of socialist realism" (Mohorovičić, 1952, 49).

The first buildings were designed by the interwar architects of Zagreb modernism: Božidar Rašica, Neven Šegvić, Drago Galić, and others that, in a specific way, combined two urban principles: free-plan modernism and space-enclosing "place making" (Blau, Rupnik, 2007, 187). However, those principles are not only formatively, but rather philosophically different: a city block assumes a clear border between private and public space, whereas a free plan presumes a general public nature; that is, sociability. By the time construction of Vukovar Street was finished, this idea was completely enlivened, in both the form and comprehension of architecture and space.

From the very beginning of building Vukovar Street, the process of creating it was carefully documented and this was disseminated among various groups in the form of postcards. New architectural aesthetics, new materials, a new relation towards space, private and public, and new housing culture were all radically different aspects from previous ones (the functionalistic city of the 1930s, a precursor of the micro-district, did not have such an expanse). That revolution needed the strong support of an ideological program, which, at that time, had a potential to radically change habits and ways of thinking. Žarko Domljan finds the "absence of a critical-theoretical sphere" $(1969,4)$ to be the key fact for illustrating postwar architecture. The rational argumentations that explain the necessity of construction that rejects the city-block approach to urban planning were also very significant. "It is very important that, instead of those barriers, buildings on pillars be built, to enable views and movement in all directions, to create recreation opportunities for children and adults. The surface of land should be left for man to walk on and an open view at least up to the level of the ground floor" (Bakrac, 1974, 4). 
However, what arose as the main question of this radical interruption of tradition are the ways this new practice was accepted or imposed on social habits. Because there was a bold awareness of Zagreb as a medieval and nineteenth-century city, located in a clearly defined area, building such a diverse and large urban fabric demanded proper social marketing. One of its undoubted aspects were countless workers' movements that encompassed large numbers of men and women, motivated by the creation of the new Zagreb socialism, with new opportunities for brotherhood and unity. The other, more subtle, level of social communication was the media and tourism materials such as postcards that tried to define Vukovar Street as the new urban icon.

Over the years, iconicity was integrated into the major buildings that were built on the edges of Vukovar Street: the City Hall (1958), Worker's University (1960), Hall of Justice (1970), Vatroslav Lisinski Concert Hall (1973), and Public Accounts Service (1981), which represented temples of power, culture, and the planned economy. The construction of the two intersecting streets, University Mall (Sveučilišna aleja) and Miramar Street (Miramarska cesta), with their prominent buildings, delineates the western and eastern axis of the "Green Horseshoe" (Zelena potkova) string of parks in the area from the railway to the Sava River (Blau, Rupnik, 2007, 194), which clearly marks not only the idea of connecting new and old Zagreb, but also the need to understand this new approach with the same sense of iconicity as in the project by Milan Lenuzzi (a.k.a. Lenuci).

Popularization of this new artery in the socialist city was supported by a strong marketing campaign that, in addition to the traditional motifs of the old city center with St. Mark's Church and the cathedral, to a large extent presents various views on Vukovar Street, especially with the distinguished City Hall. Particularly interesting for analysis is the mix of compositions combining traditional symbols with, for example, the building of the $\mathrm{Fa}$ culty of Humanities and Social Sciences, the Faculty of Mechanical Engineering and Naval Architecture, and the Open University or highway. This iconographic clash actually functions as a buffer that transfers the undoubtable iconicity of the cathedral, Lotrščak Tower, Stone Gate, and National Theater to the newly established symbols of prosperity, technical modernity, and humanistic democracy. The construction project represented not 
only the construction of housing, but the construction of a homeland, as well as direct participation. This was demonstrated on postcards with the motifs of workers' campaigns, in which men and women stood side by side, under the slogan of brotherhood and unity, participating in this sacred process. The uses of advertising established a completely new set of ideological and social values, a new architectural urban system, and a new iconography represented by workers and the products of their labor.

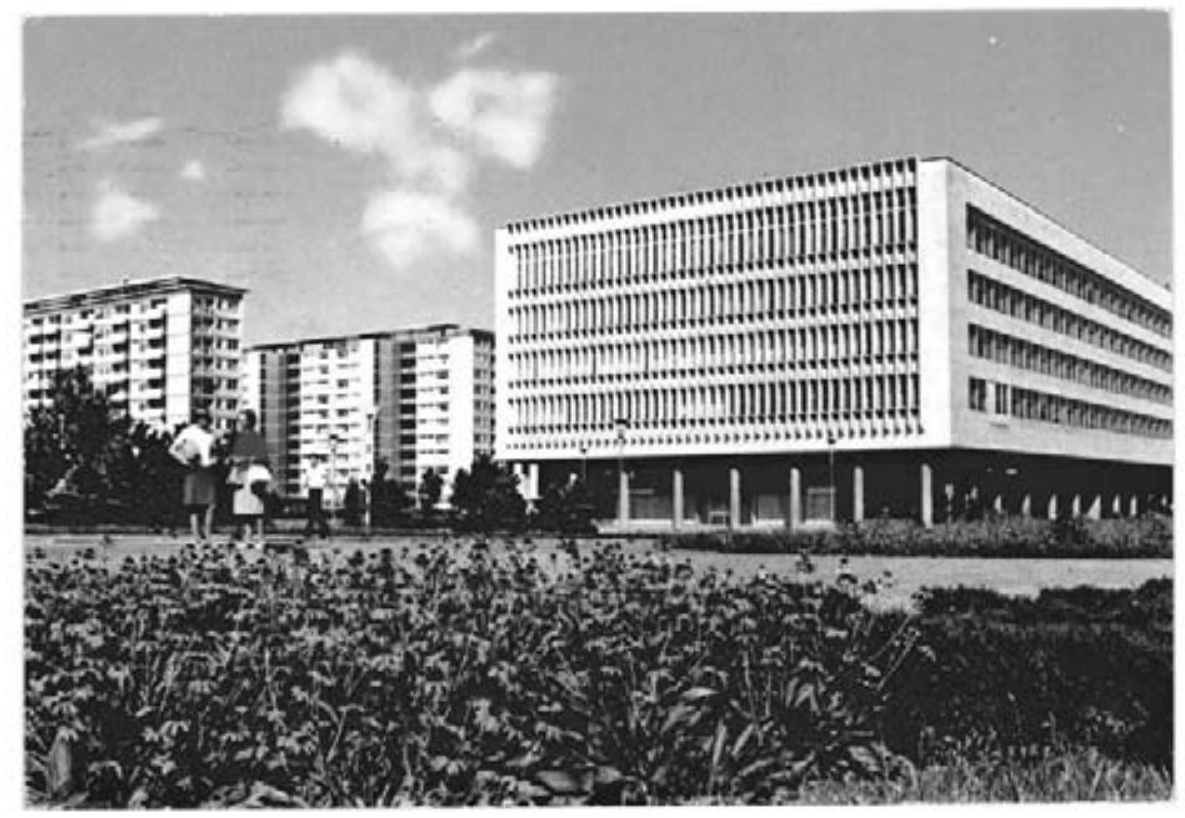

figure 3: Postcard with Vukovar Street - left: residential building by Drago Galić, 1956-59, right: City Hall by Kazimir Ostrogović, 1955-57 source: Croatian State Archives

\section{The Zagreb Fairground}

The history of fairs in Zagreb begins in the thirteenth century in the Grič neighborhood, which under a Golden Bull of Hungarian King Béla IV gained the status of a free royal town. By the eighteenth century fairs had gradually moved to the Lower Town, on the edge of the city. In every 
following expansion of urban space, the fair moved to the new edge, where it functioned as an urbanization point for the neighboring area (Blau, $\mathrm{Ru}$ pnik, 2007, 221). The Zagreb Fair (Zagrebački Zbor), founded in 1909, was renamed the Zagreb International Fair (Zagrebački Velesajam) in 1947, thus becoming a new symbol in promoting Yugoslavia as a global force. The prewar location of the fairground on Sava Street (Savska cesta) was becoming increasingly inadequate for the ever-growing number of national pavilions, which encouraged Mayor Većeslav Holjevac to spearhead relocating the Zagreb Fair to a location on the other bank of Sava. This proposal met with disapproval from the highest governmental organs, with the excuse that the capital of the Yugoslav federation should be the fair center, but by invoking the tradition of the Zagreb Fair and owing to the strong lobbying of Mayor Holjevac, a revolutionary shift in Zagreb planning happened: the Sava was crossed and the expansion of the city towards the south began. "The new north-south highway took a 180-degree turn in Zagreb's development ... . The New Zagreb Fair south of the Sava, the first phase of this conception, sparkled in neon and fluorescent in front of thousands of visitors from Yugoslavia and abroad." (Petrović, 1956, 1)

During the Cold War, the Zagreb Fair was the only international fair that offered a common ground for exhibitors from the US, the Soviet Union, and unaligned countries (Blau, Rupnik, 2007, 216). "Zagreb acted as a catalyst. Not only commercial arrangements between our companies and foreign companies were concluded, but also between countries split by the West-East divide (Zagrebački velesajam, 1957, 5). The role of the Zagreb Fair long exceeded its commercial function. Its significance could be perceived at two main levels: national and city. At the national level, the Zagreb Fair represented commercial networking with Western countries, the East Block, and unaligned countries, cultural exchange, technological competition, and political promotion. At the city level, however, the location of the Zagreb Fair played a key role, especially from the perspective of Zagreb as a future metropolis. Its location south of the Sava, in a completely undeveloped part of the city, brought infrastructure, which proved to be the condition for building a new urban housing project: New Zagreb (Blau, Rupnik, 2007, 221). To ensuring the conditions for creating a new fairground area, the new Trnje Bridge had to be built and electricity, sewage, water, and te- 
lecommunication lines installed. Levees had to be built along the Sava. All this would not have even been initiated if the Zagreb Fairground had not been anticipated as the core of New Zagreb. The significance of the first fair on the opposite bank of Sava is proved by the fact that in 1956 the Zagreb Fair was opened by Yugoslav leader Josip Broz "Tito" himself, and the opening ceremony was transmitted by the first telecast of Zagreb Television.

The Zagreb Fairground was built following two plans, by Marijan Habrele and Božidar Rašica (Richter, 1959, 1). The latter accentuated the orientation of the fairground, in a broader urban sense, as the focus of the future city on the right bank of Sava (Rašica, 1957, Razgovor s projektantom ing. arh. Božidarom Rašicom, 1). In a conversation with Božidar Rašica, the planner emphasized this new orientation in the second phase of the fairground construction. 'The basic conception of the project is to integrate the Zagreb Fairground with other parts of the area on this bank of Sava, between the Sava and Jakuševac bridges; in other words, integration of the whole area into the urban fabric of Zagreb, which the Sava should flow through, and not past (Rašica, 1957, Razgovor s projektantom ing. arh. Božidarom Rašicom, 1). In addition, in 1957 Rašica stressed the construction of the space east and south of the Zagreb Fairground. "On available land one could finally start building housing in the manner of modern housing developments, which are the only kind that allow the large-scale, qualitative, and economical building and shaping of the city" (Rašica, 1957, Razgovor s projektantom ing. arh. Božidarom Rašicom).

"Today, trade fairs are not only economic and political events, but also events of national potential that also demonstrate to citizens what is happening in production and what level of standard has been reached" (Rašica, 1957, Zagrebački velesajam - intervju, 2). Providing simultaneous exhibitions of the world's forces facing off, competitive displays of American and Soviet space technology could be seen at the Zagreb Fair, with the display of Sputnik III in 1961 and American Mercury capsules in 1970 (Blau, Rupnik, 2007, 216). The fair was a training ground for presentations of different innovations in various sectors from all over the world, to be seen not only by professionals and politicians, but also by the vast number of new workers, which formed the majority of the population. The architecture of the pavilions was a display of modern, functionalistic architecture, and it 
was designed by the biggest names in the field: Marijan Haberle, Ivan Vitić, Božidar Rašica, Vjenceslav Richter, Drago Korbar, Aleksandar Dragomanović, and others. According to Haberle "... displays have to be attractive. The same goes for the look of pavilions, which have to be attractive in their colors and shapes' $(1959,2)$.

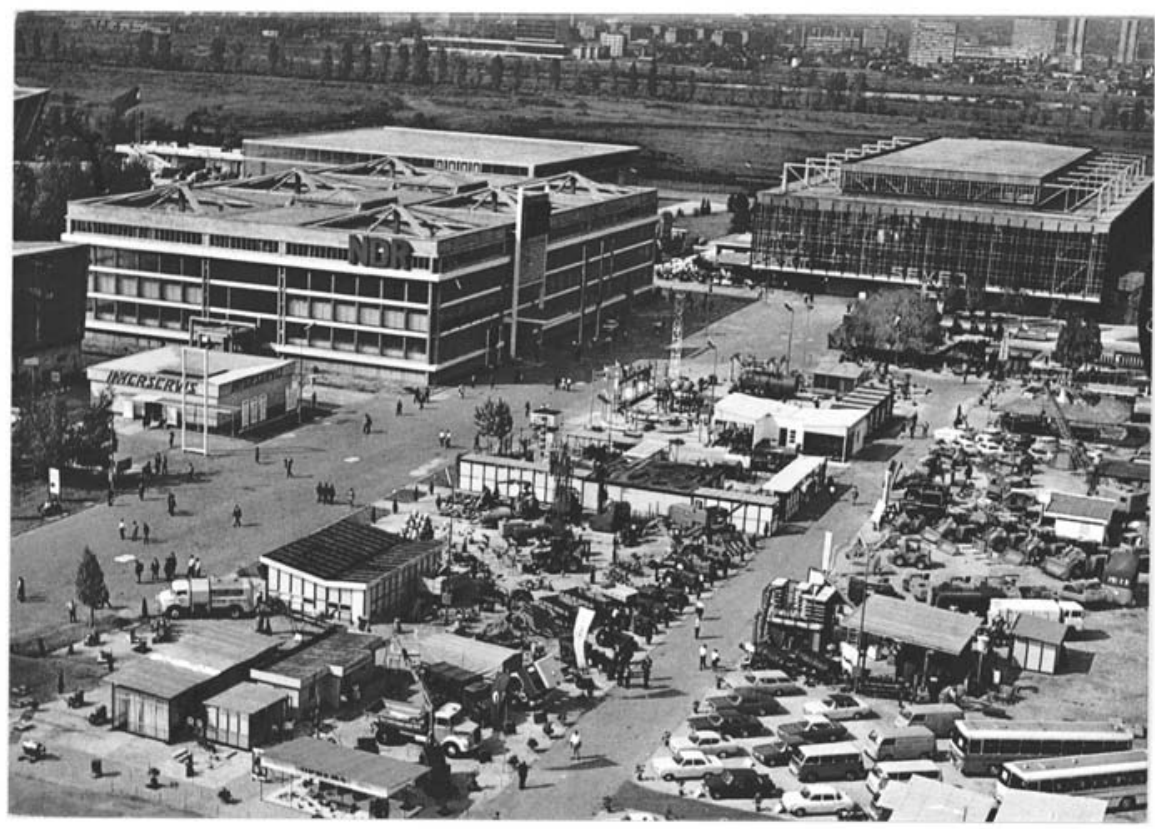

figure 4: Postcard with Zagreb Fair - from left to right: Pavilion of Eastern Germany by Bozidar Rasica, built in 1964; Pavilion of heavy industry by Bozidar Rasica, built in 1957 source: Croatian State Archives

The principles applied to the architectural construction of the Zagreb Fairground would become later the construction principles of New Zagreb. As Marijan Haberle said, it is a question of "the three economics: economics of planning the time, which is always insufficient ..., the economics, that is the purpose, of the object and, in the end, economics of price" (Habrele, 1959, 2). Furthermore, the prefabricated principle, later applied using another material for the New Zagreb apartments, was important because 
the specific pavilions had only temporarily served fair purposes and were later moved to other city locations, where their function was changed. "The structure was imagined and realized as prefabricated and de-prefabricated, and then to be moved to a given location on Prague Street (Praška ulica), after the exhibition" (Dragomanović, 1959, 3). This is how Aleksandar Dragomanović explained his basic thoughts for the construction of the Self-Service Finished Goods Pavilion. Stjepan Milković, one of the three planners of the Department Store for Family and Household Exhibition, similarly explained the style of and reasons for the construction reassembled in the Trešnjevka neighborhood. "It was necessary to demonstrate the possibility of fast and economical construction of prefabricated small department stores with specialized shops on the self-service (supermarket) principle for the commercial centers of micro-districts ... The equipment of the structures was designed from prefabricated elements." (Milković, 1959, 4) Therefore the Zagreb Fair, with its border location, not only demonstrated the new concept of modern architecture on the one hand and modes of self-service shopping on the other, but also, by being implemented into the urban fabric of the Lower Town (on Prague Street) and in the Trešnjevka neighborhood, it came into direct contact with traditional architecture.

In the new iconography of Zagreb, the fair took a solid place. It presented the city of Zagreb, the Yugoslav republic of Croatia, and the federation of Yugoslavia. It presented Yugoslavia as a modern industrialized country with strong integrative forces, which was able to gather representatives of radically opposed ideologies in one place, and demonstrate its model as the optimum form of a political and economical system: communism with elements of consumer societies. "The fair, then, followed the development of Zagreb in its urban, economic, and social basis. Its form and content are expressions of a specific time and society, and it remains so today" (Sajmovi, 1959, 1). The extent of the fair's significance for the identification process is demonstrated on numerous postcards with the motifs of national pavilions and the most modern products, as well as on pins and flags with the fair logo. This presentation of the fair was a symbolic declaration of belonging to the developed world, in whose added value the citizens of a communist country could participate. Ever since 1924, leaflets about Zagreb had been printed on the eve of the fairs; these also served as guidebo- 
oks and, when the edition was sold out, new ones with some updates were immediately published. These were the forerunners of the deluxe Zagreb monographs published after 1945 (Kolar-Dimitrijević, 1999, 320). In the media, the fair days filled the headlines; every year saw increased figures of domestic and foreign exhibitors and visitors from all parts of Yugoslavia. The success of the Zagreb Fair was also "a barometer that showed trends and tendencies faster then other marketing media” (Zdunić, 1968, 69). Although the "Zagreb Fair was founded to help the young Croatian capitalist class" (Kolar-Dimitrijević, 1999, 331), it undoubtedly became a symbol of communist prosperity. The original visitors-industrialists, merchants, and craftsmen - were replaced by the new categories of people: organized groups of workers, union representatives, youth, antifascist activists, and so on (Kraljević, Arčabić, 2006, 160). The mixed symbolic forms of systems at odds with one another were quite common and were present in public communication during the entire period from the Second World War until 1990 , and until today, but in a changed language.

\section{New Zagreb}

"Every expansion of the Zagreb Fair signifies new urban changes in Zagreb (Trnsko, Savski Gaj, and other housing developments), and impacts the rate of economic development, the population's living standard, and shifts in its social and ethnic structure, and at the same time encourages new population movements as well as an entire chain of new economic activities and cultural, art, and political events" (Kolar-Dimitrijević, 1999, 338). Therefore, the planning of new housing areas in the southern part of the city was already implemented in the idea of moving the Zagreb Fairground to the right bank of the Sava. In the background of this revolutionary urban idea, there certainly was a very rapid and accelerated growth of the working population, which came from rural areas to find jobs in the numerous factories founded after the Second World War (Domljan, 1969, 6). The working class was a legitimating basis of society; it was the focus of the highest national interest, which is why residential construction, alongside industry, was a 
kind of indicator of social success. From the Second World War until 1947, 104,397 apartments were built in Zagreb (Stipetić, 1974, 19).

The situation in Zagreb at the time was fairly specific. In fact, the historical center was almost completely built up, so it was vital to find an undeveloped city area whose open space would enable the development of completely new urban planning, coordinated with the material and spiritual needs of new man. The construction of Vukovar Street was the first step, but, although partially residential in function, it was just a testing ground for preparing the real integration of the southern part into the city as a whole. The jump over the Sava was facilitated by the infrastructure supplied by the fair; filling the green expanses with such housing developments was to demonstrate that the New Zagreb of socialist society remained to be accomplished. It was estimated that this area would be settled by 250,000 people (Kolacio, 1962, 1). Residential, leisure, work, and traffic issues were the priorities that had to be secured. In this project it meant building neighborhoods, micro-districts, and districts. "This created an opportunity to clearly and functionally connect primary and secondary units into a unified urban whole" (Kolacio, 1962, 5). Although the housing developments are very different, their main characteristic is to satisfy the planned functions. Cultural and social functions were left for future times with a more lavish public life, but have not yet been realized. Although planned for, a qualitative new value was not accomplished. However, the theoretical argumentations that could be read in trade journals such as Arhitektura (Architecture) and Čovjek i prostor (Man and Space) spoke in favor of new micro-districts to make life more human, with plenty of sun and air, with greenery and the togetherness of the residents, whose isolation was almost impossible (Begovic, 1962, 6-7).

Considering that the population living in New Zagreb came mainly from rural areas, with underdeveloped habits of urban dwelling, the critique of particular deficiencies was left out. The voice of the professional community also praised the results of communist planning as that which enabled everybody to live in a quality environment, and it emphasized that under communism urban planning played a much greater role than under capitalism (Savez arhitekata Jugoslavije, 1962, 6). Moreover, the category of "socially owned" apartments (company-owned apartments or buildings 
for indefinite use by their residents) had a number of semantic levels: the positive human relation of the communist system towards the worker, without negative connotations for that type of resident (Franić, Korlaet, Vranić, 2005 199), wealth of the country that can afford this, and the solidarity of the workers themselves, who were ready to participate in public activities to assist such construction.

New Zagreb, burdened by economizing the production costs of the dwelling units, encouraged experimentation with new construction methods and techniques. The Jugomont Company manufactured the JU 61 system, which consisted of prefabricated concrete construction and replaceable aluminum skins. Construction was significantly accelerated, standardized, and flexible (Blau, Rupnik, 2007 260), and thus cheap. The apartments were popularly referred to as "cans" and were conceived of as "dwelling machines" appropriate for their inhabitants: industrial workers.
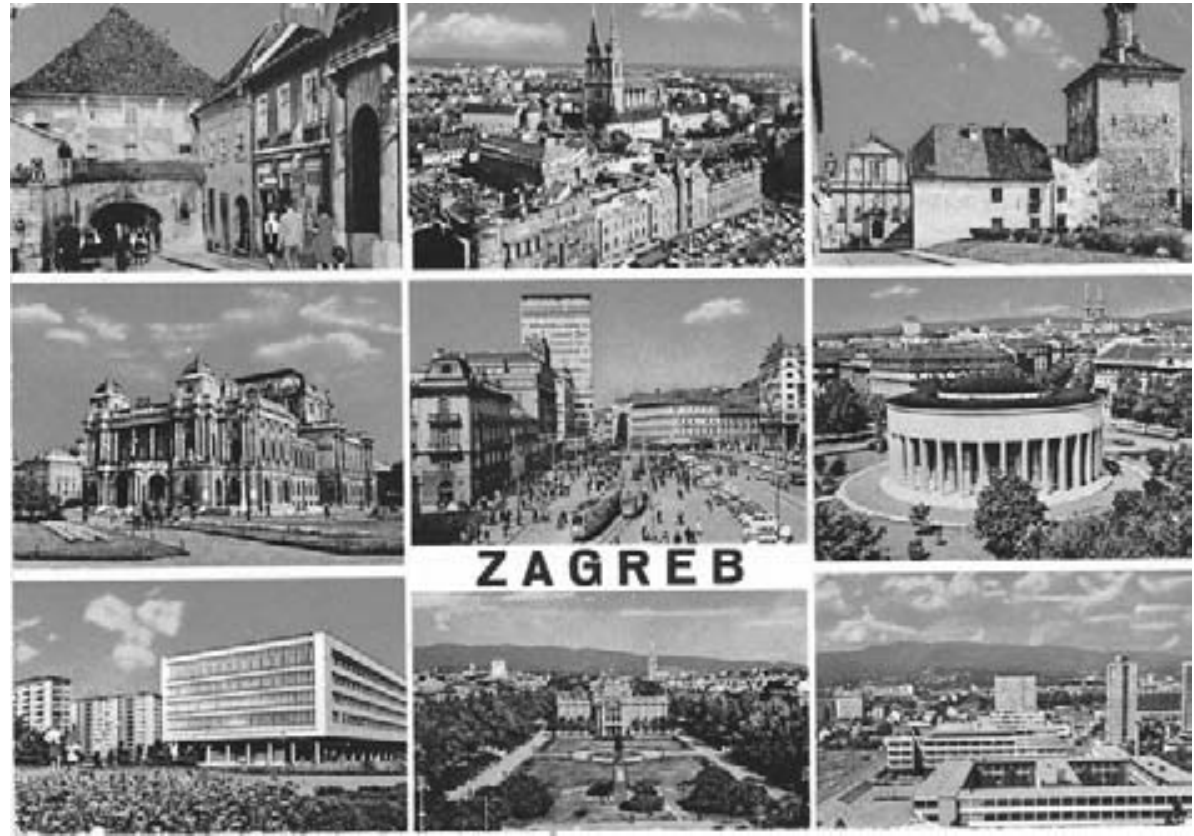

figure 5: Postcard with motives of Zagreb - from left to right: the Stone Gate, the Cathedral, Lortrscak Tower, National Theater, Ilica Skyscraper, Museum of the Revolution, the City Hall, Art's pavilion, University Allee source: Croatian State Archives 
These new residential districts, the planning experiments under the new conditions, were popularized in several ways. In addition to the positive critique and intensive theoretical discussions in popular magazines and trade journals, new tourist maps marking New Zagreb were printed. Bus tours were arranged to show a new standard of living in the greenery and sun, near places of work, with direct traffic connections to the old center. In the same manner, the Ikom Company, a pin foundry, produced pins promoting the new urban creations. One had the slogan "Building Zagreb across the Sava" and another "With workers' solidarity 1,000 new apartments." Souvenirs such as pins and postcards function as iconic forms that disseminate the symbolic values of a society among the wider community and dictate which forms summarize the qualities of a specific time and space.

\section{The Želipoh Building}

Aside from huge urban projects, Zagreb as a metropolis has also been built on limited but very important locations of the nineteenth-century Lower Town. In this area of the first modernization, bourgeois city-block-based architecture arose, and its historicist, classicistic, and secessionist forms created a regular rectangular grid with clear borders between public and private space. Although the main buildings and spatial complexes were created south of the railway, interpolations were a challenge. Among the most controversial, from its very beginning and still today, has been the Željpoh building, designed by Stanko Fabris. This glass structure was placed on the northwest corner of Marshal Tito Square (Trg maršala Tita), near the Arts and Crafts Museum by Hermann Bolle, the National Theater by Fellner and Helmer, the University Rectory by Ludwig Zettl, and other protected historical buildings. Having in mind the sensitivity of the surroundings, the construction of the Željpoh building was preceded by intense professional discussions that regulated the final result to a great extent. "In his design Fabris was obliged to obey predetermined conditions, the same adopted by the Town Planning Institute on the recommendation of Neven Šegvić and Josip Seissel." (Vukadin, 2007, 228) However, at the very beginning of its construction, those institutions that approved the project and gave directi- 
ons demanded suspension of the construction and announced new bidding for the new structure (Vukadin, 2007, 231). That demand was refused, and the building was finished considerably differently from Fabris' project, and discussions about its quality and its integration within the environment did not abate until the announcement of the new bidding in 1990 for a redesign of the Music Academy.

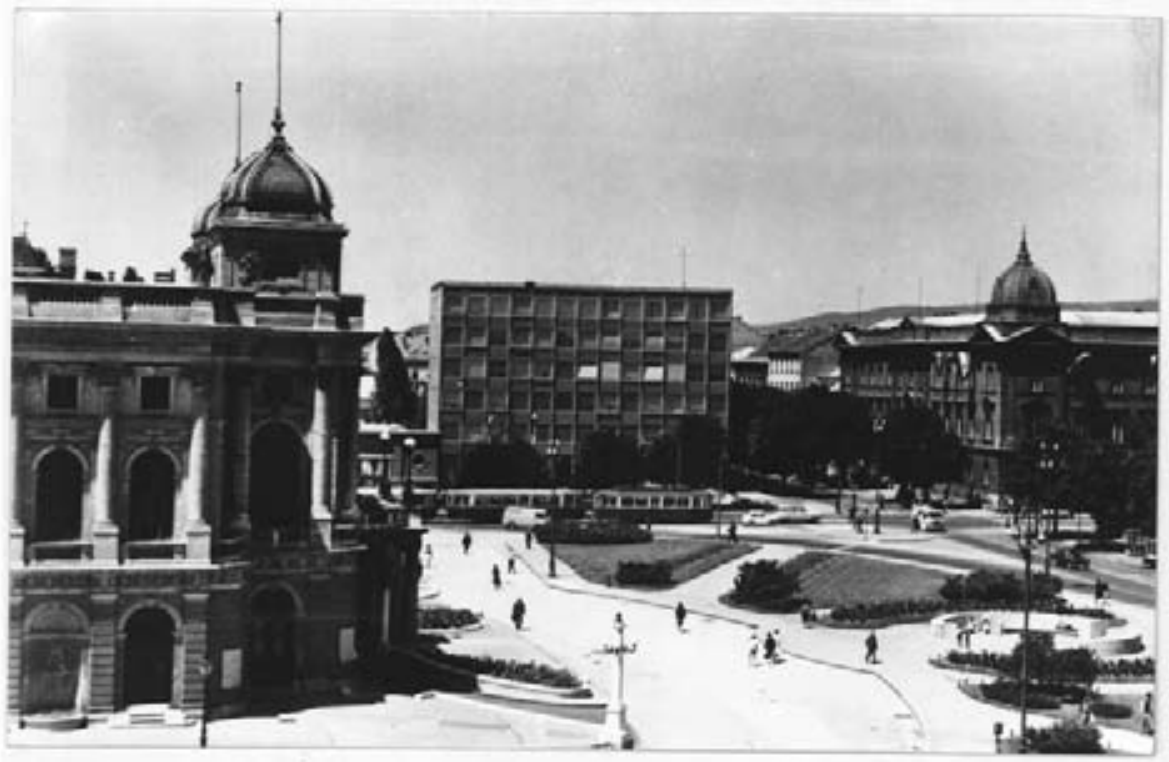

figure 6: Postcard with Zeljpoh Building (S. Fabris, 1964) in the middle, National Theater on the left and Lexicographic Institute on the right source: Croatian State Archives

Those controversies resulted in two parallel processes. First, there was a very detailed analysis of the structure that was created as typical architecture of its time, following the ideal of Mies van der Rohe (Vukadin, 2007, 232) and following the interpolation method of contrast that was characteristic for this period. Second, there was an attempt to turn this architecture into an acceptable image of the city. With no respect for argumentation clearly defending the position of the architect Fabris, the public had a negative relation towards the Željpoh building. This negativity was even expressed 
in a survey conducted in 1997, when the public placed the building high on the list of places that aroused displeasure (Stiperski, 1997, 314). Although the dialogues about architecture held in Otocac in 1962 dedicated special attention to the relation between architecture and the public, and emphasized the importance of the public influence on forming public awareness about the necessary support for progressive orientation in architectural production (Divac, 1962, 3), the Željpoh building remained on Marshal Tito Square, increasingly distorting the image of the city due to neglect and deterioration. The tendencies to integrate Fabris' building, a witness of modern architecture and one of the first buildings with a suspended-curtain facade in Croatia, into the visual picture of the Lower Town successfully combines the traditional and the modern. It harmoniously integrates two different architectural and ideological languages, seen in a number of postcards that, side by side with the temples of nineteenth-century culture (the National Theater and the Lexicographic Institute), also show the Željpoh building.

\section{The Ilica Skyscraper}

The Ilica Skyscraper (1959, designed by Slobodan Jovičić, Josip Hitil, and Ivan Žuljević) was the first building in Croatia with a glass-curtain facade. In addition, this is the only high structure $(64 \mathrm{~m})$ on the central square in the Lower Town, Ban Jelačić Square (Trg bana Josipa Jelačića). The idea of a skyscraper at this location originated in 1929 (Mutnjaković, $1959,5)$, and therefore all the theories that the skyscraper is an ideological counterpoint to the cathedral are flawed arguments. A tender was announced to build a skyscraper, and all the applicants offered to build a high structure. However, Mutnjaković believed that the vertical accent should have been even bolder than realized, thinking that the creation was too modest a breakthrough.

Independent from criticism then and now, the Ilica Skyscraper has become an urban accent of the Lower Town, burdened with a variety of symbolic connotations. In the media, especially during the communist era, it was one of the most common postcard motifs, often photographed at night under 
the lights of the metropolis with associations of its New York forerunner. It is its location that is focal; aluminum glass construction, the most modern building in communist Zagreb, located in the very heart of the nineteenth-century fairground. Shining in the daylight, reflecting the sun, and artificially lit at night, the Ilica Skyscraper, like every other skyscraper, was a visual focal point and simultaneously a symbol of the modernity of Zagreb architecture and interpolation. This is why it entered the city's iconography; in addition to modernity it also embraced the content of tradition.

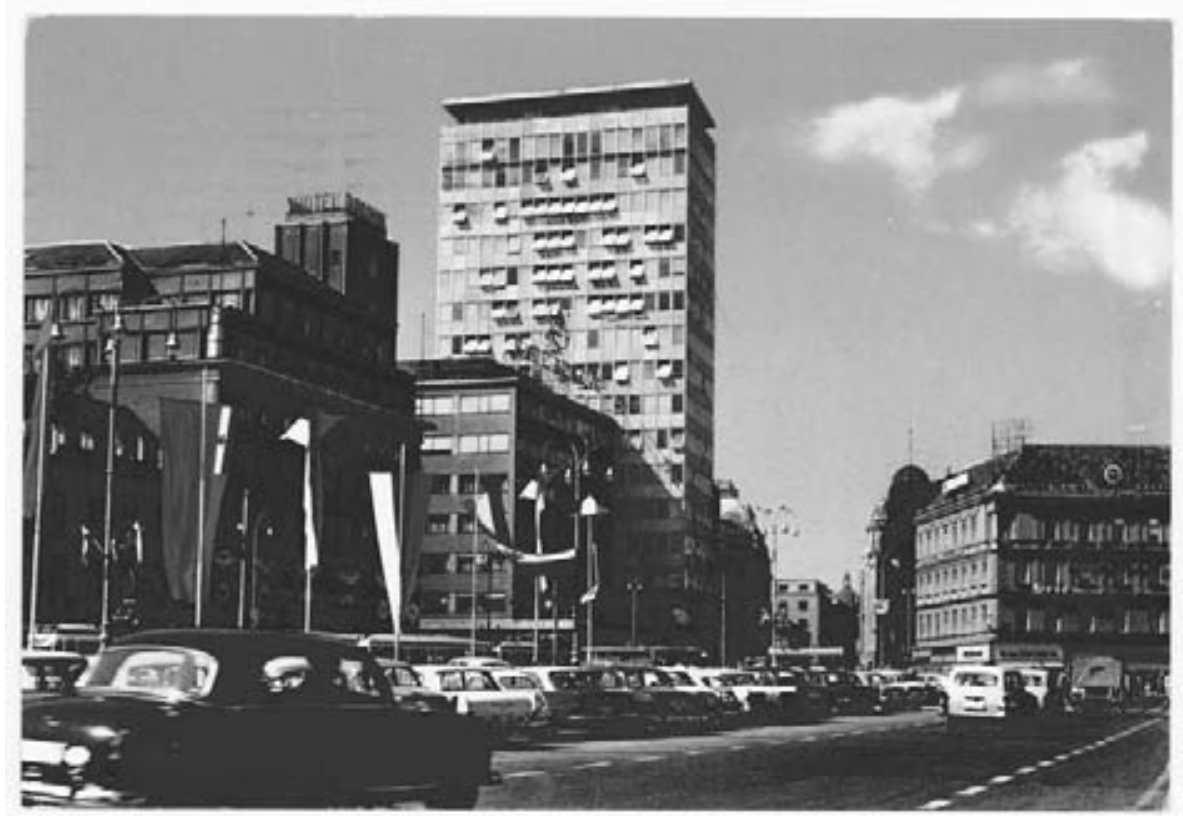

figure 7: Postcard with Ilica Skyscraper (S. Jovicic, S. Hitil, I. Zuljevic, 1959) at night source: Croatian State Archives

\section{The Universiade}

The Zagreb Universiade, held in 1987, was not only a sports event, but an incentive to renovate the city's infrastructure (Zekić, 2007, 299). On this occasion, a number of sports, cultural, and hotel facilities were built 
in Zagreb, such as the Mimara Museum, the Cibona Business Center, the Mladost, Salata, and Jarun stadiums, the Vjesnik Tower, the bus terminal, and the Dubrovnik Hotel. Other activity took place a well; for example, Republic Square (Trg Republike, today Ban Jelačić Square) was renovated, around 60 facades were refurbished, a folklore festival was held, the Eurokaz international theater festival was launched, and new galleries were opened. The entirety was "a program of social infrastructure" with the aim of being a foundation for development of the city and the country as a whole (Pavić, 1987, 2-3). Through such broadly set goals of the Universiade, Yugoslavia sought to overcome a significant economic crisis and present itself in an international context as an economic power to be contended with. The Universiade was marked by very intense positive political maneuvers that not only reinforced the notion of brotherhood and unity, but also involved a very extensive building program to beautify the city's image.

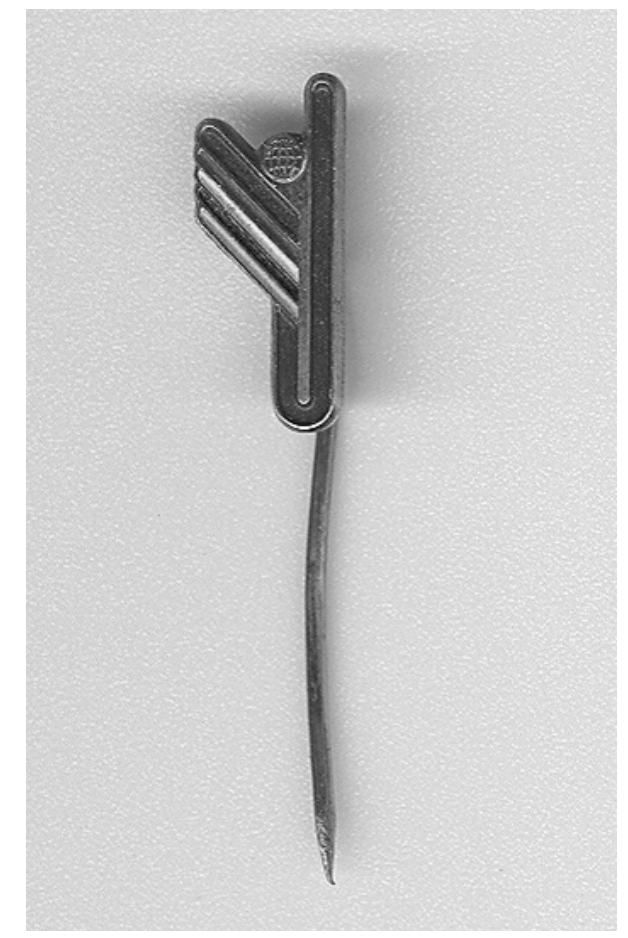

figure 8: Pin with the Universiade mascot Zagi, designed by Nedjeljko Dragić source: I. Podnar 
To promote this huge sports event, in addition to designing the mascot Zagi, which was disseminated in all possible media from toys and pins to facades and flags, very intensive promotion was organized for every new structure built for this occasion. These automatically gained symbolic meaning and assumed iconic status. Numerous postcards with the Cibona Tower and the Dubrovnik Hotel were printed; pins were made with the figure of Zagi, the Volleyball Club, and so on. The Universiade became a very powerful symbol of Zagreb, and all the structures and activity that it created became a permanent reminder of this international success. In 1987, only three years before the disintegration of Yugoslavia, this event was used as an attempt to attain national cohesion and to obscure Yugoslavia's enormous economic problems. In this situation Zagreb, although at the time only a capital of a Yugoslav republic, was able to bring together economic, infrastructure, sports, and cultural factors, pointing to its future as a metropolis.

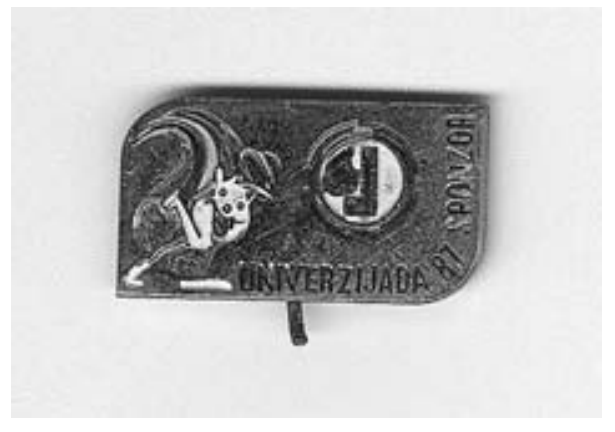

figure 9: Pin with motif of Zagi source: I. Podnar

\section{Conclusion}

The metropolitan character of Zagreb, observed in the period of its second modernization, is identified through the parallel processes of creating new and nourishing inherited symbolic forms that coexist as complementary systems in a social group's awareness. The first modernization, during prewar capitalism, announced the formation of this future metropolis and 
therefore tried to create urban architectural foundations for its potential realization. It was absolutely clear that the development of Zagreb in the second modernization would not take the same course but, by using alternative spatial forms, would create Zagreb's framework primarily as an industrial center directed towards an urban establishment, synchronized with all other industrial cities in Yugoslavia.

By contextualizing the general aspirations of spatial formation, Zagreb constructed a combined model in a dialogue with the old and new, the city-block and free plan, communist and capitalist, to create a very specific identity system. This system can be recognized in a wide acceptance of differences: Zagreb is equally defined by the Stone Gate, the cathedral, and St. Mark's Church, as well as by the City Hall, the Ilica Skyscraper, the Zagreb Fairground, the Open University, New Zagreb, and so on. The symbolic forms of different social systems, at least in their secondary presentations, gained a similar level of communicational frequency. However, at the same time it should be remembered that all the propaganda instruments, especially after the Second World War, were in the hands of the ruling class, and therefore it is hard to assume what the real extent was of the level of symbolic integration of both models.

Excluding this factor, and basing the analysis on concrete material, the tendency of new architectural forms as bearers of quite clear ideology to build upon the symbolic capital already present is completely evident. This is how many interesting derivatives were created, such as Zagreb's traditional coat of arms, to which a red five-pointed star was added, or postcards that together with the National Theater and Lotrščak Tower depict the skyscrapers in New Zagreb, faculties from University Mall, City Hall, and other elements. Traditional symbols are still dominant in these pastiches, but the newly established ones can certainly be seen alongside them. In most tourism material, Zagreb is still presented as a medieval and nineteenth-century city. A small portion of this material explicitly reinforces the new ideological figures: postcards with factory chimneys, workers' demonstrations, marching officers, pins showing the new highway or the Pioneer Town (Pionirski grad) communist youth camp, and so on. 
The identity systems of every specific time are materialized in urban forms, and in their continuance their meanings are always newly interpreted. The communist period cultivated a relatively negative relation towards the urban and architectural shapes that preceded it, which was manifested towards the space of the Lower Town, whereas the Upper Town remained outside the ideological discourse despite the fact that churches and state institutions are located there. However, systems are created as continuities, which is why some periods simply cannot be left out but, based on their identifications, those symbolic constructs that least differ from the desired ones should be selected. This method enables maximum participation in building new identity systems, the aim of which is to create urban icons. The development of Vukovar Street, the Zagreb Fairground, or New Zagreb was in a continuous dialogue with the city on the left bank of Sava. Even in form, the views towards the old city center were not closed off, but there was an attempt to produce a positive dialogue and mutual affirmation in the identification of contemporary Zagreb.

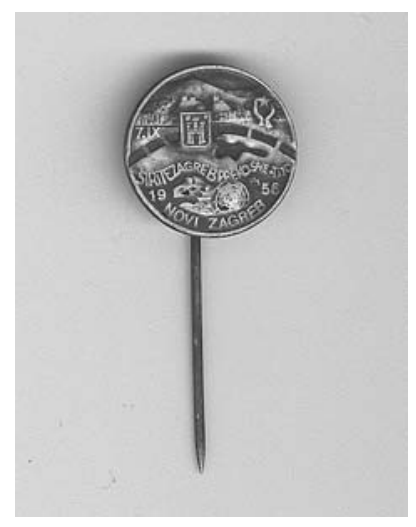

figure 10: Pin with the sign 'Building Zagreb across Sava' source: I. Podnar

For this analysis, tourism propaganda materials such as postcards and pins were chosen that were most accessible to broad social classes and in whose production aesthetic criteria stood behind the silent language of ideology and state marketing. Apparently these benign, very mundane, and cheap souvenirs were the ideal agents of communication, and their simple 
visual language was very understandable. However, as often is within the "normal," "ordinary," and "acceptable," those unquestioned categories became signs and images of more complex relations in the context of a specific time and space. While viewing the postcards and pins with motifs of $\mathrm{Za}$ greb, still nonexistent symbolic elements were revealed: the buildings on Vukovar Street, parts of the Zagreb Fairground and New Zagreb, and the glass structures of the Željpoh building and the Ilica Skyscraper. They were shown independently or in combination with traditional motifs.

Pins are, however, the souvenirs that are most often connected with the logos of Yugoslav economic giants. They were equally fitting as small-scale posters with messages or symbols referring to the construction of New Zagreb or individual structures created for the Universiade, and the logos of the Zagreb Fair, which simultaneously functioned as an economic, architectural, and urban entity. These pins would not only be attractive marketing for a specific industry, but marketing of specific urban politics.

The postcards and pins with Zagreb motifs from the communist period themselves present a set of new urban motifs that, via integration within the content of the most frequent visual materials, precisely aimed at positioning them as the new iconic places. By cataloguing and analyzing those new motifs, an integral image is derived, showing what Zagreb considered its identity from the end of the Second World War until 1990. The materials demonstrate that the identity of Zagreb by no means denied its traditional symbolic places, but that there were attempts to add a new set of urban signs to its existing symbolic capital.

\section{REFERENCES}

Bakrac, Boris. "O poslijeratnoj stambenoj izgradnji u socialističkoj republici Hrvatskoj.” Arhitektura 149 (1974): 4.

Begovic, Miroslav. "Dinamika života, prostora i arhitekture." Čovjek i prostor 107 (1962): 6-7. 
Blau, Eve, and Ivan Rupnik. Project Zagreb: Transition as Condition, Strategy, Practice. Barcelona: Actar, 2007.

Divac, Olga. "Arhitektura i javnost." Čovjek i prostor 117 (1962): 3.

Domljan, Žarko. "Poslijeratna arhitektura u Hrvatskoj." Život umjetnosti 10 (1969): 4-45.

Dragomanović, Aleksandar. "Zagrebački velesajam - intervju." Čovjek $i$ prostor 82 (1959): 2.

Franić, Tin Sven, Luka Korlaet, and Dubravla Vranić. "Prilog analizi stambenih politika i planske stanogradnje Nizozemske i Hrvatske." Prostor 13.2 (2005): 196-206.

Habrele, Marijan. “Zagrebački velesajam - intervju." Čovjek i prostor 82 (1959): 1-2.

Ivanković, Vedran. "Moskovski boulevard - Ulica grada Vukovara u Zagrebu 1945.-1956. godine." Prostor 14.2 (2006): 178-95.

Kolacio, Zdenko. “Južni Zagreb.” Čovjek i prostor 116 (1962): 1-5.

Kolar-Dimitrijević, Mira. "Projekt povijesti Zagrebačkog velesajma iz 1967. godine: u povodu 90-godišnjice Velesajma." Časopis za suvremenu povijest 31.2 (1999): 319-39.

Kraljević, Iva, and Goran Arčabić. "Zagreb Fair in 1947.: The First Fair Trade Exhibition in the Post-War Yugoslavia" [sic]. Časopis za suvremenu povijest. 2.1 (2006): 153-64.

Milković, Stjepan. "Zagrebački velesajam - intervju." Čovjek $i$ prostor 82 (1959): 4.

Mohorovičić, Andrija. "Analiza historijsko-urbanističkog razvoja grada Zagreba." Rad Jugoslavenske akademije znanosti $i$ umjetnosti (1952): 27-52.

Mutnjaković, Andrija. “Zagrebački neboder." Čovjek i prostor 92 (1959): $1-3$.

Pavić, Nino. "Velika predstava može početi, Zagreb je već pobijednik." Vjesnik 14302 (1987): 2-3.

Petrović, Branko. "Bio sam posjetilac kraj 17520. Između htjenja, mogućnosti i kreativne snage." Čovjek i prostor 54 (1956): 1.

Rašica, Božidar. "Razgovor s projektantom ing. arh. Božidarom Rašicom.” Čovjek i prostor 67 (1957): 1-6. 
Rašica, Božidar. “Zagrebački velesajam - intervju.” Čovjek $i$ prostor 82 (1959): 1-2.

"Razgovor s projektantom ing. arh. Božidarom Rašicom." Čovjek i prostor 67.4 (1957): 1-6.

Richter, Vjenceslav. "Još dva urbanistička problema grada Zagreba." Čovjek i prostor 82 (1959): 1.

Rogić, Ivan. “The Metropolitan moves of the First Modernization.” u: »Project Zgareb (Eve Blau i Ian Rupnik) (2007): 39-41.

"Sajmovi." Čovjek i prostor 82 (1959): 1.

Savez arhitekata Jugoslavije. "Otvorena pitanja arhitekture i urbanizma." Čovjek i prostor 116 (1962): 6.

Stiperski, Zoran. Mjesta u Zagrebu - sinonimi za ugodu i neugodu. Prostor 5.2 (1997): 307-20.

Stipetić, Davor. "Stambena arhitektura ili arhitektura stambene krize." Arhitektura 149 (1974): 19-20.

Vukadin, Ana. "Gradnja poslovne zgrade Željpoh (Ferimport) na Trgu maršala Tita u Zagrebu." Prostor 15.2 (2007): 224-35.

“Zagrebački velesajam.” Čovijek i prostor 67.4 (1957): 5.

Zdunić, Drago. (ed.). Zagreb: The Fair City. Zagreb: Pomurski tisk, 1986.

Zekić, Jasenko. "Univerzijada '87. - drugi ilirski preporod." Časopis za suvremenu povijest 39.2 (2007): 299-318. 


\section{PODOBA ZAGREBA KOT DRUGE METROPOLE SFRJ}

Ključne besede: urbane ikone, urbanistični razvoj povojnega Zagreba, modernizem $\mathrm{v}$ arhitekturi, zagrebške vedute na razglednicah, simbolične podobe Zagreba na značkah

\section{Povzetek}

Raziskava odpira pogled na dinamiko urbanega razvoja Zagreba kot metropole v socialistični dobi, kakor se kaže na izbranem široko dostopnem (v veliki meri turistično obeleženem) likovnem materialu, kot so razglednice in značke. $Z$ analizo motivov, ki se v tovrstnem materialu pojavljajo kot najbolj reprezentativne podobe Zagreba v določenih obdobjih, študija razkriva ideološke vidike, ki se skrivajo tako v izboru motivov kot v njihovi predstavitvi.

V zgodnjem povojnem obdobju sta bila v Zagrebu realizirana dva velika urbanistična projekta: Ulica grada Vukovara, reprezentativni center pomembnih vladnih, administrativnih in kulturniških stavb, ter razstaviščni kompleks Zagrebškega velesejma, s katerim je bil storjen radikalen korak $\mathrm{v}$ širitvi mesta $\mathrm{v}$ južni smeri in izgradnji Novega Zagreba na desnem bregu Save. Ta dva revolucionarna projekta sta morala funkcionirati v okviru aktualnega političnega diskurza, hkrati pa je bilo potrebno sprejetje $\mathrm{s}$ strani najširše družbene sfere - delavskega razreda. Abstraktna arhitekturna govorica modernizma je bila za večji del te družbene sfere (ki je bila do nedavnega pretežno ruralnega značaja) težko sprejemljiva. Manjši del prebivalstva je imel drugačno socialno poreklo - to so bili meščani, ki so živeli v starem mestnem jedru. To je zanje predstavljalo »pravi« Zagreb, zato so bili do novonastalih urbanističnih projektov zadržani iz drugačnega razloga. Naloga široko zastavljene medijske kampanje je bila torej nove podobe Zagreba približati obema skupinama in vzpodbuditi proces prepoznavanja novih urbanističnih projektov kot njunega mesta - spodbujati identifikacijo prebivalcev s konceptom mesta, ki je vpeto v sodobne urbanistične tokove. 
Da bi uspešno implementirali nove simbolične podobe Zagreba $v$ družbeno zavest meščanov, so njihovi snovalci uporabili preizkušene mehanizme medijske propagande. Prizadevali so si, da bi postale čim bolj vidne tudi za tiste, ki ne živijo v njihovi bližini. Hkrati so jih premišljeno povezovali z mestnimi znamenitostmi, ki so že bile vsesplošno sprejete kot ikonične, in to $\mathrm{z}$ namenom povzdigniti jih na isto raven oziroma jim dodeliti enako simbolično vrednost. Rezultat je bil indikativen izbor urbanih vedut, s katerimi so poskušali vizualizirati idejo Zagreba kot prestolnice ene od republik SFRJ - Zagreb, ki je urbano središče s pomembnimi spomeniki iz različnih zgodovinskih obdobij, od srednjega veka do najnovejše dobe, hkrati pa napredno evropsko mesto, ki v polni meri sledi sodobnim trendom arhitekturnega in urbanističnega razvoja.

$Z$ natančnim sledenjem upodobitev Zagreba na razglednicah in značkah $\mathrm{v}$ času socializma se vzpostavi zemljevid, ki jasno razkriva prioritete splošnega urbanističnega razvoja tako $\mathrm{v}$ velikem merilu kot $\mathrm{v}$ posameznih detajlih: od celih mestnih četrti, kot sta Zagrebški velesejem in Novi Zagreb, do enako indikativnih posamičnih interpolacij, kot sta stavba Ferimporta in nebotičnik na Ilici. Vsi ti projekti so imeli izjemno velik vpliv na družbeno okolje, saj so vnesli nova funkcionalna in estetska merila, obenem pa posredovali ideološke, politične in kulturne vrednote. Njihovo razširjanje v obliki razglednic in značk je funkcioniralo kot oblika tihe, vendar uspešne propagande nove vizualne in idejne podobe Zagreba kot metropole, ki zavestno gradi lastno identiteto. 